Review

\title{
Cross-Talk between NADPH Oxidase and Mitochondria: Role in ROS Signaling and Angiogenesis
}

\author{
Tohru Fukai ${ }^{1,2}$ and Masuko Ushio-Fukai ${ }^{1,3, *}$ \\ 1 Vascular Biology Center, Departments of Pharmacology and Toxicology, Medical College of Georgia at \\ Augusta University, Augusta, GA 30912, USA; tfukai@augusta.edu \\ 2 Charlie Norwood Veterans Affairs Medical Center, Augusta GA 30901, USA \\ 3 Department of Medicine (Cardiology), Medical College of Georgia at Augusta University, \\ Augusta, GA 30912, USA \\ * Correspondence: mfukai@augusta.edu
}

Received: 1 July 2020; Accepted: 5 August 2020; Published: 6 August 2020

\begin{abstract}
Angiogenesis, a new vessel formation from the pre-existing ones, is essential for embryonic development, wound repair and treatment of ischemic heart and limb diseases. However, dysregulated angiogenesis contributes to various pathologies such as diabetic retinopathy, atherosclerosis and cancer. Reactive oxygen species (ROS) derived from NADPH oxidase (NOX) as well as mitochondria play an important role in promoting the angiogenic switch from quiescent endothelial cells (ECs). However, how highly diffusible ROS produced from different sources and location can communicate with each other to regulate angiogenesis remains unclear. To detect a localized ROS signal in distinct subcellular compartments in real time in situ, compartment-specific genetically encoded redox-sensitive fluorescence biosensors have been developed. Recently, the intercellular communication, "cross-talk", between ROS derived from NOX and mitochondria, termed "ROS-induced ROS release", has been proposed as a mechanism for ROS amplification at distinct subcellular compartments, which are essential for activation of redox signaling. This "ROS-induced ROS release" may represent a feed-forward mechanism of localized ROS production to maintain sustained signaling, which can be targeted under pathological conditions with oxidative stress or enhanced to promote therapeutic angiogenesis. In this review, we summarize the recent knowledge regarding the role of the cross-talk between NOX and mitochondria organizing the sustained ROS signaling involved in VEGF signaling, neovascularization and tissue repair.
\end{abstract}

Keywords: NADPH oxidase; mitochondria; reactive oxygen species; angiogenesis; redox signaling; endothelial cell; vascular endothelial growth factor

\section{Introduction}

Angiogenesis is the process of a new blood vessel (capillaries) formation from pre-existing vasculature. It is involved in physiological neovascularization such as embryonic development and wound healing and is required for vascular restoration in response to ischemia via delivering oxygen and nutrients in ischemic cardiovascular diseases. Excess and pathological angiogenesis contribute to cancer, ocular diseases such as diabetic retinopathies and atherosclerosis [1]. Thus, enhancing or inhibiting angiogenesis has great therapeutic significance. Especially, peripheral arterial disease (PAD), which is caused by atherosclerotic occlusion in the lower extremities, results in decreased blood flow and amputation of the foot or leg. Thus, promoting angiogenesis to restore limb perfusion is an important therapeutic approach for the treatment of PAD. Vascular endothelial growth factor (VEGF) is a key angiogenic growth factor that stimulates disruption of the endothelial cell (EC) 
junction, EC migration, proliferation and capillary tube formation mainly through VEGF receptor type2 (VEGFR2/Flk1) [2]. VEGF binding to VEGFR2 on the plasma membrane induces receptor dimerization and autophosphorylation, which is followed by receptor internalization (endocytosis) to early endosomal compartments where sustained VEGFR2 signaling is further activated to drive angiogenesis [3]. Other growth factors such as fibroblast growth factor (FGF), platelet-derived growth factor (PDGF) and angiopoietin-1 as well as hypoxia also promote angiogenesis in ECs.

Reactive oxygen species (ROS) (e.g., superoxide anion $\left(\mathrm{O}_{2}{ }^{-}\right)$and hydrogen peroxide $\left(\mathrm{H}_{2} \mathrm{O}_{2}\right)$ ) are toxic in excess. However, ROS at the physiological level function is essential for redox signaling involved in various biological responses including cell proliferation, migration, differentiation and gene expression [4,5]. Accumulating evidence suggests that angiogenesis can be also stimulated by ROS derived from ECs and other cell types such as vascular smooth muscle cells, myeloid cells such as neutrophils and macrophages. There are many sources of ROS including NADPH oxidases (NOX), the mitochondrial electron transport chain (ETC), xanthine oxidase, uncoupled endothelial nitric oxide synthase (eNOS), cytochrome P-450 oxygenase and cyclooxygenase. The vascular NOX isoforms (Nox1, Nox2, Nox4 and Nox5) differ in their activity and cell specificity in response to agonists, growth factors and hypoxia, and the type of ROS released after activation. In ECs, ROS derived from NOX (especially Nox2 and Nox4) in plasma membranes or intracellular cytosolic compartments [5-9] as well as mitochondria [10-12] play a key role in angiogenic response induced by growth factors such as VEGF [13]. However, the mechanisms by which highly diffusible ROS generated from different sources (enzymes) and locations can coordinate and communicate to promote a sustained growth-related angiogenic process are poorly understood.

During the past several years, the cross-talk between NOX and mitochondria, termed "ROSinduced ROS release", has been proposed as a positive feed-forward mechanism of localized ROS production to organize redox signaling [14,15]. For example, it is shown that $\mathrm{H}_{2} \mathrm{O}_{2}$ activates Nox2 or p22phox to produce $\mathrm{O}_{2}{ }^{-}$in fibroblasts and smooth muscle cells [16]; uncoupled eNOS produces $\mathrm{O}_{2}{ }^{-}$, instead of $\mathrm{NO}$, to enhance mitochondrial ROS (mitoROS) production [17,18]; NOX-derived ROS increase mitochondrial ROS [13,19]; and mitochondrial ROS stimulate NOX activation [20]. This feed-forward ROS-induced ROS release mechanism can be targeted to inhibit pathological angiogenesis associated with oxidative stress or promote ROS-dependent physiological and therapeutic angiogenesis. This review will summarize the recent knowledge regarding the role of ROS-induced ROS organized by the cross-talk between ROS derived from NOX (plasma membrane and cytosol) and mitochondria in driving angiogenesis, in particular, focusing on VEGF signaling. Understanding these mechanisms should provide new insights into therapeutic strategies for various angiogenesis-dependent cardiovascular diseases and cancer.

\section{Role of ROS Signaling in Angiogenesis}

The endothelium lines the blood vessel lumen to mediate blood flow homeostasis and tissue metabolic demands by supplying nutrients and oxygen. Healthy ECs are in quiescence but new vessel formation (angiogenesis) occurs to revascularize tissues in response to angiogenic growth factors such as VEGF released by hypoxia, nutrient deprivation or tissue injury [1]. This organized and coordinated angiogenic phenotype switch from quiescent ECs is impaired in various diseases such as diabetes and aging with endothelial dysfunction, which results in tissue ischemia, leading to ischemic cardiovascular diseases including PAD. By contrast, dysregulated and excess angiogenesis stimulates cancer and diabetic and ocular retinopathy. In adults, ROS at the appropriate level are increased in response to growth factors (e.g.,VEGF), ischemia or wound injury, which function as signaling molecules to promote the angiogenic switch from quiescent ECs (Figure 1). Excess ROS contribute to pathological angiogenesis involved in cancer, atherosclerosis and pathological retinopathy. 


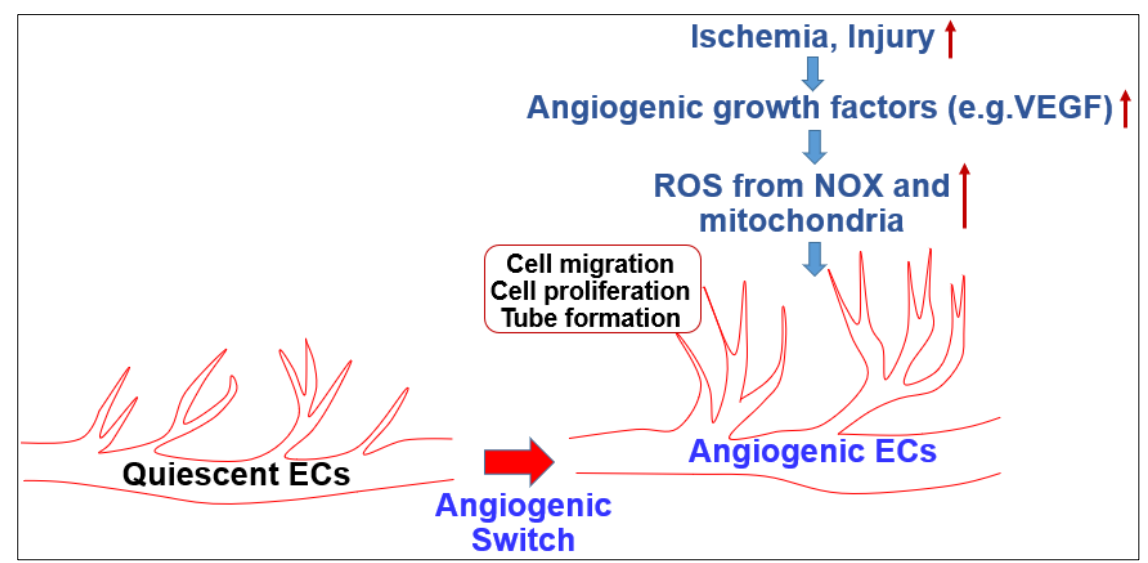

Figure 1. Role of reactive oxygen species (ROS) in angiogenesis in endothelial cells (ECs).

ROS include free radicals such as $\mathrm{O}_{2}{ }^{-}$, hydroxy radicals $(\mathrm{OH})$ and non-radicals such as $\mathrm{H}_{2} \mathrm{O}_{2}$. The $\mathrm{O}_{2}{ }^{-}$generated by various $\mathrm{ROS}$ enzymes is rapidly scavenged by superoxide dismutases (SODs including cytosolic SOD1 (Cu/ZnSOD), mitochondrial SOD2 (MnSOD), SOD3 (extracellular SOD, ecSOD, EC-SOD)) to generate $\mathrm{H}_{2} \mathrm{O}_{2}$ (Figure 2). $\mathrm{H}_{2} \mathrm{O}_{2}$ is further converted to $\mathrm{H}_{2} \mathrm{O}$ by catalase, glutathione peroxidase (GPX) and peroxiredoxins (PRXs) (Figure 2). Oxidative stress (excess ROS) contributes to pathological angiogenesis, such as tumorigenesis, diabetic retinopathy and developing hypertension, heat failure and vasculopathy [21-23]. Further, abnormal angiogenesis induced by oxidative stress plays causative roles to promote atherosclerosis by increasing both macrophage infiltration and the thickening of the blood vessel wall by oxidized low-density lipoproteins (LDLs) [22,24-26].

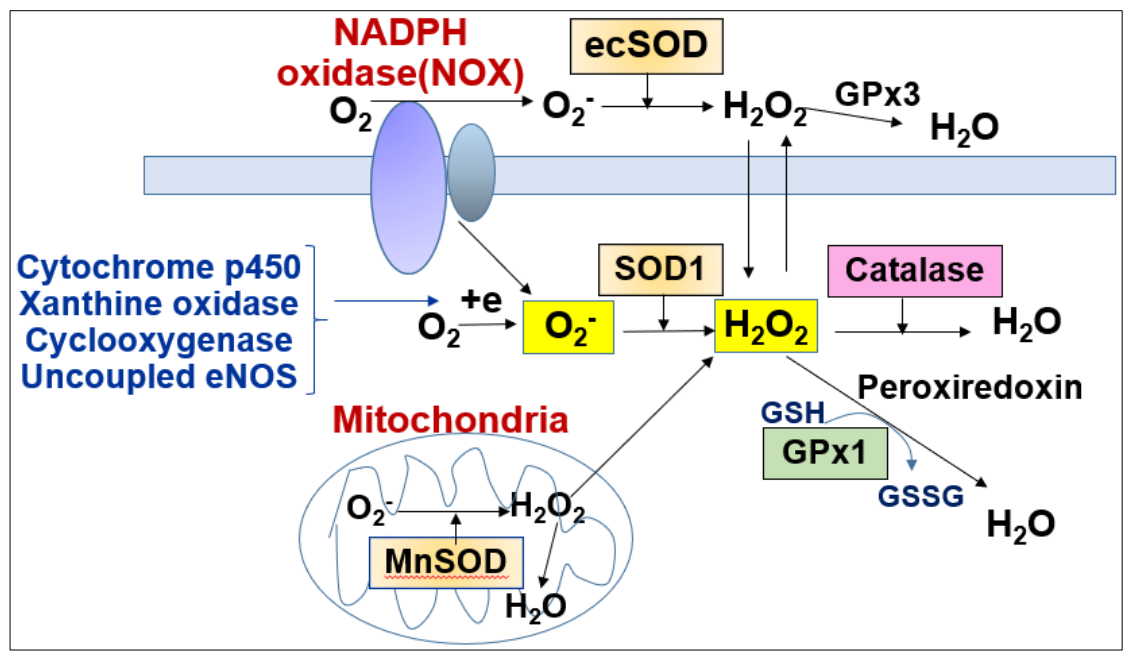

Figure 2. Generation and metabolism of ROS in ECs.

By contrast, ROS, especially $\mathrm{H}_{2} \mathrm{O}_{2}$, at optimal levels function as signaling molecules to mediate various biological responses including angiogenesis [4,5], which is required for tissue repair and remodeling [27-29]. For example, exogenous ROS increase VEGF or VEGFR2 expression [30] and stimulate EC proliferation and migration [31,32]. During wound healing, ROS induced by tissue hypoxia induce angiogenesis by stimulating VEGF production from macrophages, fibroblasts, ECs and keratinocytes [21,33,34]. We reported that endothelium-derived $\mathrm{H}_{2} \mathrm{O}_{2}$ is required for post-ischemic neovascularization in vivo by using EC-specific catalase-overexpressing mice [35]. Furthermore, we reported that VEGF-induced ROS are required for VEGFR2 tyrosine phosphorylation, EC migration and proliferation via activation of small GTPase ARF6 localized at caveolae/lipid rafts in ECs [36]. Furthermore, it is shown that ROS-mediated redox signaling linked to angiogenesis involves mitogen-activated protein kinases (MAPKs), PI3 kinase, Akt, JAK-STAT, protein tyrosine 
phosphatases (PTPs) such as protein tyrosine phosphatase 1B (PTP1B) and SH2-containing protein tyrosine phosphatase 2 (SHP2), phosphatase and tensin homolog (PTEN) as well as transcription factors including HIF- $1 \alpha$, NFkB and AP-1.

To function as secondary messengers, $\mathrm{H}_{2} \mathrm{O}_{2}$ promotes signaling by oxidizing hyperactive cysteine residues on target proteins, which exist as thiolate anions (Cys-S-) at physiological $\mathrm{pH}$. Of note, most cysteines have a pKa over 8 , and therefore they remain protonated at physiological $\mathrm{pH}$. ROS oxidize the thiolate anion to the sulfenic acid $(\mathrm{Cys}-\mathrm{OH})$, which forms a disulfide bond and alters redox signaling. Under normal conditions, this process is reversible by the disulfide reductases thioredoxin (TRX) and glutaredoxin (GRX). However, under pathological conditions with excess ROS (oxidative stress) and reduction of Trx and Grx, irreversible hyperoxidation of Cys residues (sulfinic and sulfonic acid) can be formed. Using "redox-dead" Cys17Ser PKARI $\alpha$ knock-in mutant mice, Burgoyne et al. [37] reported that PKARI $\alpha$ oxidation and dimerization-mediated activation is involved in VEGF-, tumorand ischemia-induced angiogenesis. By contrast, the cytosolic receptor tyrosine kinase domain of VEGFR2 has two oxidation-sensitive Cys residues and is kept in a reduced state by antioxidant enzyme PRX-2 in quiescent ECs. However, Prx2 deficiency in quiescent ECs increases Cys oxidation of VEGFR2, thereby forming disulfide bonds, which in turn inactivates VEGFR2 that cannot respond to VEGF [38]. Thus, keeping quiescent ECs at a reduced state is important for driving an ROS-dependent VEGF-VEGFR2-stimulated angiogenic switch. Recently, we reported that redox-sensitive Cys residues of mitochondria fission protein Drp1 are kept in a reduced state by ER-localized thiol oxidoreductase protein disulfide isomerase (PDIA1) in quiescent ECs [39]. Reduction of PDIA1 in diabetes increases $\mathrm{Cys-OH}$ formation of Drp1 at the mitochondria-associated membrane (MAM), thereby promoting mitochondrial fragmentation and excess mitoROS production, which results in EC senescence and impaired angiogenesis [39]. These results suggest that redox regulation of the ER-mitochondria cross-talk at MAM by oxidoreductase PDI plays an important role in maintaining quiescent EC integrity. This might be required for driving efficient angiogenic responses induced by ROS-generating angiogenic growth factor VEGF.

\section{Role of NOX in Angiogenesis}

NOX generates $\mathrm{O}_{2}{ }^{-}$or $\mathrm{H}_{2} \mathrm{O}_{2}$ by catalyzing the transfer of electrons from NADPH to reduce oxygen via their NOX catalytic subunit. The NOX family consists of seven isoforms including Nox1, Nox2, Nox3, Nox4, Nox5 and Duox1/Duox2 which localize at distinct subcellular compartments within the cells [40-42]. Their expression level is organ- and cell type-specific, and the type of ROS released and regulation of their activity are also different. The transmembrane catalytic subunits Nox1, Nox2, Nox3 and Nox4 interact with the small transmembrane regulatory subunit p22phox, while Nox5, which is not expressed in rodents, does not require a regulatory subunit for its activation. Duox 1 and 2 require Duoxa1 and Duoxa2 as a scaffold for their function [41,43]. Each NOX contains six transmembrane domains and a cytoplasmic domain that binds NADPH and flavin adenine dinucleotide, and each isoform has specific cytosolic subunits.

In ECs, major source of ROS are Nox1, Nox2, Nox4 and Nox5 [41-45]. Nox4 is the most highly expressed NOX in ECs. Although Nox1, Nox2 and Nox5 are $\mathrm{O}_{2}{ }^{-}$-generating enzymes, Nox4 overexpression increases primarily $\mathrm{H}_{2} \mathrm{O}_{2}$ [40-42,46] due to an extended extracytosolic loop [47]. Nox5 is activated in a $\mathrm{Ca}^{2+}$-calmodulin-dependent manner $[40,41,48]$ (Figure 3). Prototype Nox2 (gp91phox) was first discovered as a phagocytic oxidase to kill bacteria by generating $\mathrm{O}_{2}{ }^{-}$[49] and consists of membrane-bound catalytic subunit Nox2 and regulatory small subunit p22phox, and cytosolic subunits p47phox, p67phox and a small $\mathrm{G}$ protein Rac to produce $\mathrm{O}_{2}{ }^{-}$that is rapidly dismutated by SODs to generate $\mathrm{H}_{2} \mathrm{O}_{2}$ [50] (Figures 1 and 2). Nox1 and Nox4 catalytic subunits also couple with p22 $2^{\text {phox }}$, but Nox1 oxidase activity requires cytosolic NOX activator 1 (NOXA1) and NOX organizer 1 (NOXO1), which are isoforms of $\mathrm{p} 47^{\text {phox }}$ and p67phox , respectively (Figure 3). Nox4 is constitutively active without classical cytosolic subunits but is activated by polymerase delta-interactive protein 2 (Poldip2) (Figure 3). Poldip2 was originally reported as a cytosolic binding 
partner for the Nox4-p22phox complex in vascular smooth muscle cells (VSMCs) [51]. However, recent studies show that Poldip2 is a mitochondrial protein that regulates the activity of the TCA cycle and metabolic reprograming [52] as well as a regulator of the differentiated phenotype in VSMCs [53]. Using Poldip2-depleted HUVECs and Poldip2 ${ }^{+/}$mice, Poldip2 is shown to be involved in serum-induced EC proliferation and post-ischemic neovascularization [54]. Another Nox4-interacting protein is calnexin, which may be needed for the proper maturation, processing and function of NOX4 in the endoplasmic reticulum (ER) [55] (Figure 3).

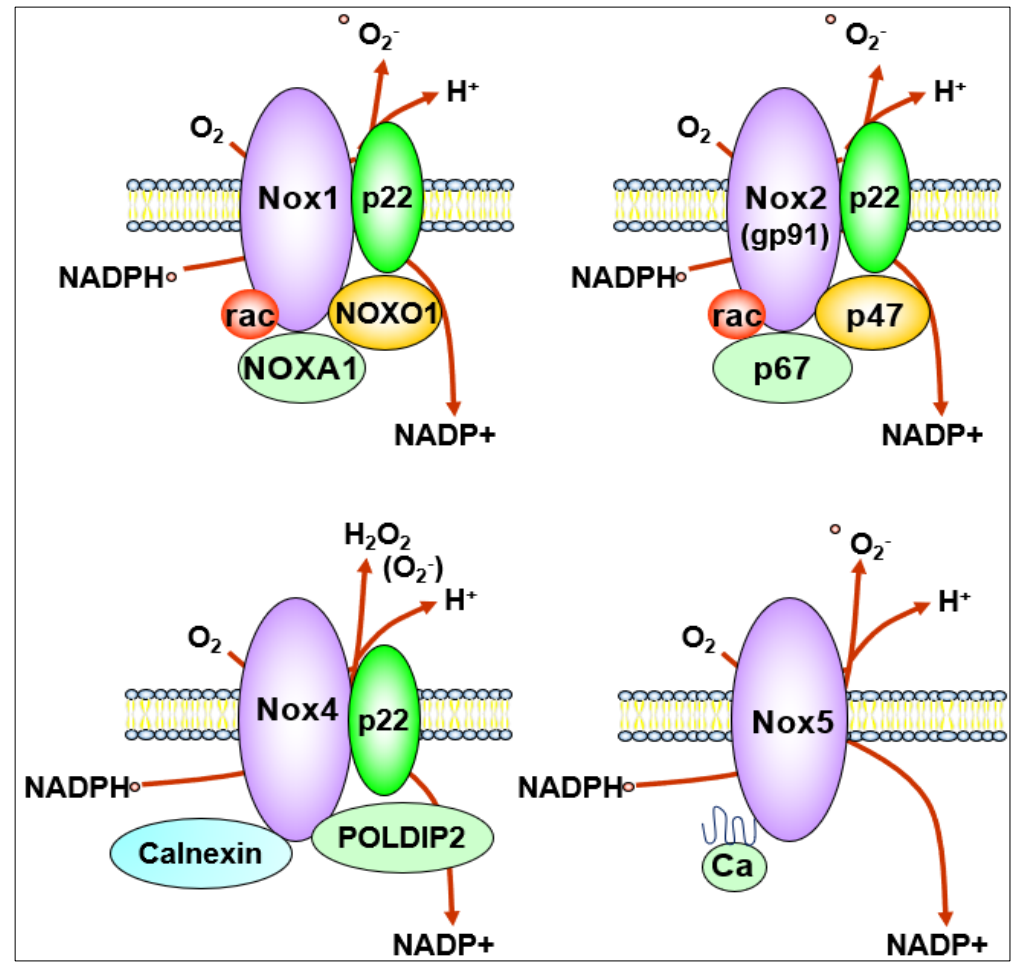

Figure 3. NOX isoforms expressed in endothelial cells.

NOX-derived ROS are required for angiogenic response induced by various growth factors

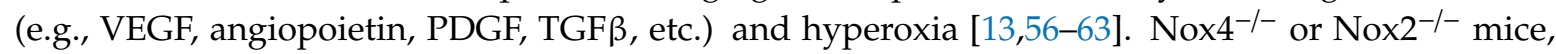
EC-specific Nox4, dominant-negative Nox4 or EC-specific catalase-overexpressing mice $[35,41,64,65]$ reveal that Nox 2 or Nox 4 or their regulators are required for ROS-dependent angiogenic signaling in ECs, tumor angiogenesis as well as post-ischemic neovascularization using a PAD model [8,36,59,62,65-75]. However, Nox2 and Nox4 also induce EC dysfunction depending on their subcellular localization, extent and duration of activation [45,76]. Indeed, hyper Nox2 activation which produces overproduction of ROS contributes to various pathologies such as diabetes, hypertension and ischemic stroke [77-82].

Compartmentalization of the ROS signal is essential for specific activation of redox signaling after receptor activation. Nox2 and Nox4 exist in diverse subcellular compartments such as plasma membranes including caveolae/lipid rafts, endosomes, ER and mitochondria $[6-9,83,84]$. During directional migration, Nox2 translocates to lamellipodia and membrane ruffles via binding to $\mathrm{p} 47 \mathrm{phox}$ with the scaffold proteins TNF receptor associated factor 4 (TRAF4) and WASP family verprolin homologous protein 1 (WAVE1)/Rac1, a cytosolic component of Nox2. Using a cell-permeable biotin-labeled Cys-OH trapping probe [85], we showed that VEGF stimulation increases Cys-OH formation of scaffold protein IQGAP1 that binds to active VEGFR2 and Rac1 at the lamellipodial leading edge, which promotes directional EC migration $[66,86,87]$. We also found that IQGAP1-deficient mice show impaired post-ischemic neovascularization using a PAD model [88]. These results suggest that Nox 2 binding to adaptor/scaffold proteins which translocate to the lamellipodial leading edge is required for localized ROS production and Cys oxidation of ROS targets, thereby promoting EC migration and 
angiogenesis [6-8]. In addition, ROS induce oxidative inactivation of PTPs which are localized at distinct subcellular compartments. This establishes compartmentalization of ROS-dependent tyrosine kinase signaling pathways involved in angiogenesis.

ROS production is also localized via NOX interaction with signaling platforms associated with lipid rafts and caveolae as well as endosomes [6,8]. We demonstrated that ecSOD-derived $\mathrm{H}_{2} \mathrm{O}_{2}$ induces Cys oxidation/inactivation of PTP1B and density-enhanced phosphatase 1 (DEP1) in caveolae/lipid rafts, thus enhancing VEGFR2 signaling and angiogenesis in ECs, which is required for restoring neovascularization induced by tissue ischemia [89]. There is also evidence that Nox4 is found in the nucleus, indicating its involvement in redox-responsive gene expression [83]. Thus, targeting NOX or its binding partners to discrete subcellular compartments is a mechanism of localizing ROS production and its downstream redox signaling events involved in angiogenesis and other biological responses.

\section{Role of Mitochondria-Derived ROS in Angiogenesis}

Not only NOX but also mitochondria-derived ROS function as a tightly regulated redox signal that transmits information from the organelle to the cell. Mitochondria are redox-active organelles and transfer more than $90 \%$ of the electron to $\mathrm{O}_{2}$ to generate $\mathrm{O}_{2}{ }^{-}$as the terminal electron acceptor [90]. The mitochondrial inner membrane contains five multiprotein complexes such as Complex I (NADH-quinone oxidoreductase), Complex II (succinate dehydrogenase), which transfers electrons into the chain from succinate, Complex III (coenzyme Q: cytochrome C oxidoreductase), Complex IV (cytochrome C oxidase) and Complex V (ATP synthase). During cellular respiration, the electrons released from the electron transport chain (ETC) react with $\mathrm{O}_{2}$ to produce $\mathrm{O}_{2}{ }^{-}$[91]. Complexes I and III are the main sites of electron transfer to $\mathrm{O}_{2}$ to produce $\mathrm{O}_{2}{ }^{-}$which is released into the intermembrane space (IMS) or matrix and is involved in redox signaling [92], because it has easier access to the cytosol. Since $\mathrm{O}_{2}{ }^{-}$is a charged species, it cannot diffuse across mitochondrial membranes. Thus, the voltage-dependent mitochondrial anion channel (VDAC) seems to help in releasing the intermembrane mitochondrial $\mathrm{O}_{2}{ }^{-}$to the cytosol [93]. In addition, $\mathrm{O}_{2}{ }^{-}$produced in the mitochondrial matrix or IMS is rapidly converted to $\mathrm{H}_{2} \mathrm{O}_{2}$ by SOD2, or SOD1, respectively, and this $\mathrm{H}_{2} \mathrm{O}_{2}$ can diffuse through both inner and outer mitochondrial membranes to the cytosol to activate redox signaling. $\mathrm{H}_{2} \mathrm{O}_{2}$ is also further converted to $\mathrm{H}_{2} \mathrm{O}$ by GPX or PRX or catalase.

Mitochondria function as an $\mathrm{O}_{2}$ sensor and transmit a hypoxic signal by releasing ROS to the cytosol [94]. Hypoxia stimulates mitoROS production such as $\mathrm{H}_{2} \mathrm{O}_{2}$ from mitochondrial complex III and the ROS trigger HIF1- $\alpha$ stabilization [94-96], which in turn increases the transcription of angiogenic genes such as VEGF [97]. Thus, mitochondria regulate angiogenic responses by controlling cellular metabolism linked to mitoROS. In ECs, not only Nox2 and Nox4 but also mitoROS play an important role in VEGF- and angiopoietin 1-induced angiogenic responses [13,98,99]. In addition, mitochondrial respiratory chain complex III (QPC) is shown to be necessary for EC proliferation involved in retinal and tumor angiogenesis [100]. MitoROS also promote ligand-independent $\mathrm{H}_{2} \mathrm{O}_{2}$-induced transactivation of VEGFR2 [101]. By contrast, mitoROS generated in hyperglycemia induce ligand-independent but Src-dependent phosphorylation of VEGFR2, which reduces the amount of VEGER2 at the cell surface required for VEGF binding, thereby attenuating VEGF-induced pro-angiogenic effects in diabetes with oxidative stress [102]. These results suggest that mitoROS produced in physiological and pathological conditions have an opposite impact on VEGFR2 signaling and angiogenesis.

\section{ROS-Induced ROS Release}

It remains unknown how ROS derived from distinct compartments communicate and affect cell function differentially [22]. Zorov et al. reported that the photodynamically produced initial phase of mitoROS caused the mitochondrial permeability transition (MPT) with a delayed amplified phase of mitoROS generation in cardiac myocytes (termed mitochondrial "ROS-induced ROS release") [14]. Chung et al. showed that sodium salicylate-induced ROS stimulate ROS as well 
as mitochondrial membrane potential collapse, which leads to cytochrome $c$ release and caspase activation [103]. In cardiac cells, mitochondrial permeability transition pore (mPTP)-dependent and independent ROS-induced ROS are observed: Increased ROS induce mPTP-dependent mitochondrial depolarization, resulting in a short-lived ROS production derived from mitochondrial ETC. By contrast, mPTP-independent ROS stimulate the opening of the inner mitochondrial membrane anion channel, which in turn stimulates ETC-derived ROS release to the cytosol. This ROS-induced ROS release creates a positive feedback mechanism for enhanced ROS production among neighboring mitochondria, leading to mitochondrial and cellular injury [104]. The organelle excitability function for electrical and $\mathrm{Ca}^{2+}$ signals of mitochondria further amplify ROS signaling [105,106]. It is proposed that $\mathrm{H}_{2} \mathrm{O}_{2}$ induces cysteine oxidation of mitochondrial proteins including ETC proteins to enhance mitochondrial $\mathrm{O}_{2}{ }^{-}$production [107], which is rapidly converted to $\mathrm{H}_{2} \mathrm{O}_{2}$ by SOD1 at IMS or SOD2 at the mitochondrial matrix, thereby further increasing mitochondrial ROS production. Thus, ROS-induced ROS release amplifies the ROS signal among each subcellular compartment [13-15].

There are several reports showing the role of ROS-induced ROS release involved in cardiovascular diseases (CAD). Li et al. [16]. demonstrate that exogenous exposure of VSMCs and fibroblasts to $\mathrm{H}_{2} \mathrm{O}_{2}$ induces $\mathrm{O}_{2}^{-}$production via non-phagocytic oxidase Nox2, thereby amplifying the vascular injury process. Zinkevich et al. reported that flow-induced $\mathrm{H}_{2} \mathrm{O}_{2}$ production and dilation in microvessels from CAD patients involves Nox2-derived ROS-induced mitochondrial ROS release [23]. In addition, Angiotensin II (Ang II)-induced Nox1 activation stimulates mitochondrial ROS, resulting in mitochondrial dysfunction and vascular senescence $[108,109]$. It is also reported that Nox2 stimulates mitoROS by activating reverse electron transfer and phosphorylation of CSrc in human aortic ECs, which contributes to Ang II-induced hypertension [110]. On the other hand, it is shown that mitochondrial ROS can stimulate NOX-derived ROS. For example, mitoROS induce activation of Nox in phagocytes and cardiovascular tissues, which in turn results in immune cell activation and development of Ang II-induced hypertension $[20,111,112]$. Thus, cross-talks between mitochondria and NOX in pathological conditions may represent a feed-forward vicious cycle to amplify excess ROS leading to oxidative stress, which can be a therapeutic target [19] (Table 1).

Table 1. Role of ROS-induced ROS release in angiogenesis and vascular disease.

\begin{tabular}{ccccc}
\hline & Cell Type & ROS-Induced ROS Release & Response or Function & Reference \\
\hline 1 & VSMC/fibroblast & H2O2-p22phox(NOX2)-ROS & Cell injury and damage & {$[16]$} \\
\hline 2 & adipose arterioles & Nox2-mitoROS & Flow-induced dilation & {$[23]$} \\
\hline 3 & VSMCs & Nox1-mitoROS & $\begin{array}{c}\text { AngII-induced } \\
\text { senescence }\end{array}$ & {$[108]$} \\
\hline 4 & leukocytes or aorta & p47phox (NOX2)-mitoROS & $\begin{array}{c}\text { AngII-induced } \\
\text { hypertension }\end{array}$ & {$[111]$} \\
\hline 5 & VSMC & MitoROS-Nox1-ROS & $\begin{array}{c}\text { Ang II-induced NOX } \\
\text { activation }\end{array}$ & {$[112]$} \\
\hline 6 & EC & Nox2-mitoROS & $\begin{array}{c}\text { AngII-induced } \\
\text { hypertension }\end{array}$ & {$[110]$} \\
\hline 7 & EC & Nox4-Nox2-ROS & $\begin{array}{c}\text { EC migration } \\
\text { (angiogenesis) }\end{array}$ & {$[65]$} \\
\hline 9 & EC & Rac1 (NOX2)-mitoROS & $\begin{array}{c}\text { EC migration } \\
\text { (angiogenesis) }\end{array}$ & {$[98]$} \\
\hline
\end{tabular}

\section{The Crosstalk between NOX and Mitochondria (ROS-Induced ROS Release) in Angiogenesis}

The role of ROS-induced ROS release in VEGF signaling and angiogenesis remains elusive. To address this question, we performed real-time imaging by using cytosol- and mitochondria-targeted 
ratiometric redox-sensitive green fluorescent proteins (RoGFP) biosensors in human ECs [113]. This method allows us to determine the temporal-spatial relationship for VEGF-induced ROS production from the different subcellular compartments. We found that VEGF stimulation in human ECs rapidly increases NOX-derived $\mathrm{H}_{2} \mathrm{O}_{2}$ in the cytosol as shown by the PEG-catalase-inhibitable cytosolic RoGFP oxidation (first phase), followed by sustained $\mathrm{mitoH}_{2} \mathrm{O}_{2}$ production as shown by the mitochondrial RoGFP oxidation [13] (second phase) (Figure 4). With other data using gain and loss of function approaches for Nox4 or Nox2, we demonstrated that Nox4-derived $\mathrm{H}_{2} \mathrm{O}_{2}$ stimulates Nox2 to increase mitoROS, which promotes sustained VEGFR2-mediated angiogenic responses in ECs [13]. An alternative method to monitor intracellular $\mathrm{H}_{2} \mathrm{O}_{2}$ in different compartments includes a redox-active biosensor, Hyper, but the signal can be affected by $\mathrm{pH}$ changes and is insensitive to reducing stimuli. Recently, an improved version of Hypers has been reported to overcome these problems [114-116]. Consistent with our report, Evangelista et al. [65] also reported that Nox4-derived $\mathrm{H}_{2} \mathrm{O}_{2}$ can activate Nox2, which contributes to VEGF-induced S-glutathiolation of the sarco(endo)plasmic reticulum $\mathrm{Ca}^{2+}$-ATPase (SERCA) and EC migration likely at MAM [117,118]. Thus, these finding suggest that ROS-induced ROS release orchestrated by Nox4, Nox2 and mitochondria plays an important role in driving angiogenic phenotypes from quiescent ECs (Table 1).

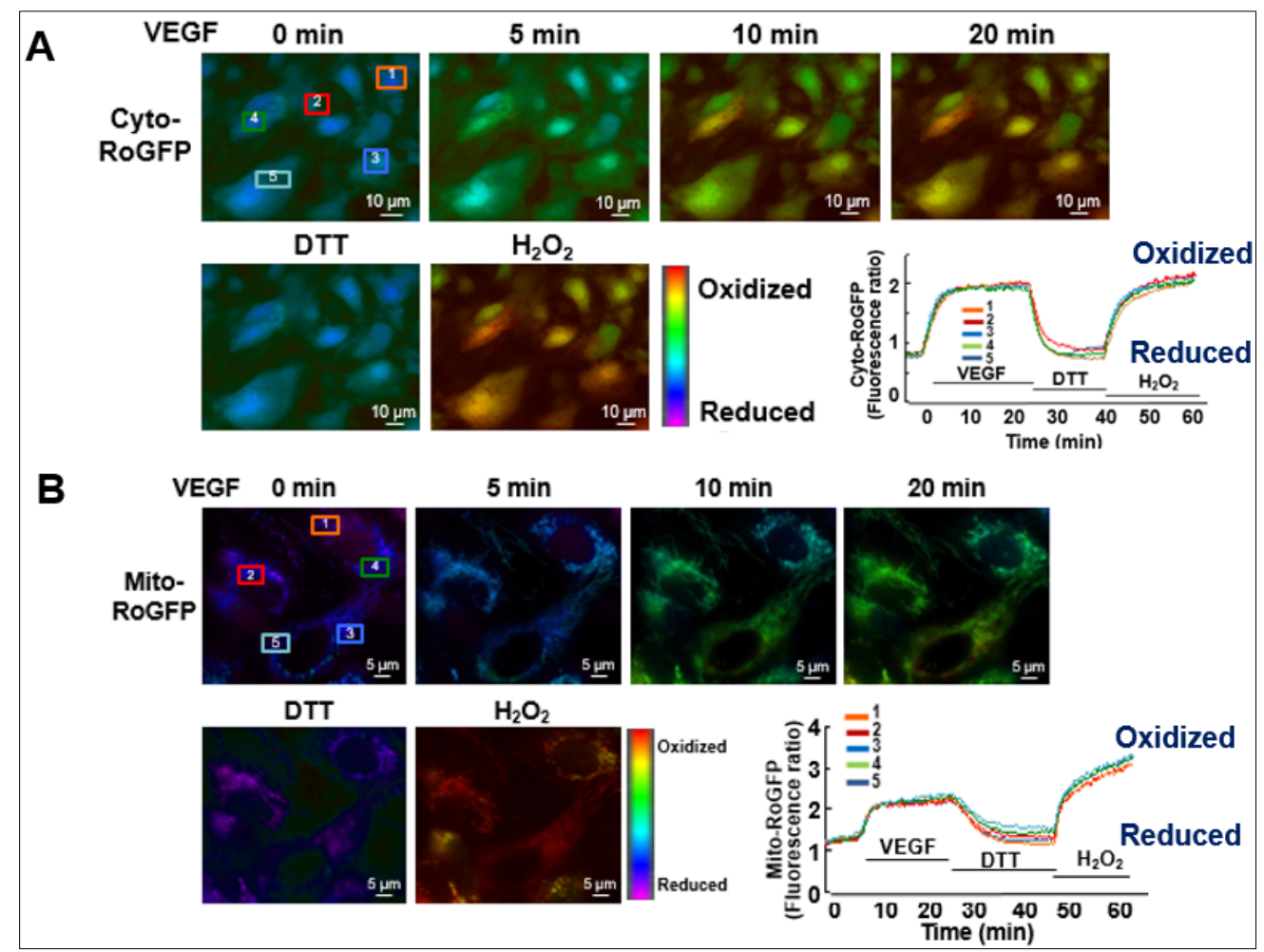

Figure 4. Real-time imaging for cytosolic and mitochondrial redox status in single cell in response to VGEF.

It remains unclear how VEGF rapidly activates Nox4 to induce $\mathrm{H}_{2} \mathrm{O}_{2}$ in ECs. It is reported that insulin-like growth factor 1 (IGF-I) induces rapid Nox4 $\operatorname{Tyr}^{491}$ phosphorylation, which promotes rapid and localized ROS production via Nox4 binding to the adaptor protein growth factor receptor bound protein 2 (Grb2), which is in a multifunctional transmembrane glycoprotein, $\mathrm{SH} 2$ domain-containing protein tyrosine phosphatase substrate 1 (SHPS-1) complex. Thus, similar mechanisms may be involved in VEGF-induced rapid Nox4-mediated $\mathrm{H}_{2} \mathrm{O}_{2}$ production in ECs. It also remains unclear how Nox4-derived $\mathrm{H}_{2} \mathrm{O}_{2}$ can activate Nox2. Based on the literature, it is possible that $\mathrm{H}_{2} \mathrm{O}_{2}$ produced by Nox4 activation may activate Nox 2 via phosphorylation of Nox2 or its cytosolic organizers such as p47phox and Rac1 [41,98,119]. To support this, it is shown that $\mathrm{H}_{2} \mathrm{O}_{2}$-induced activation of 
redox-sensitive kinase cSrc can phosphorylate p47phox [41] and Rac1 guanine nucleotide exchange factor Vav2 [120] that activates Rac1 in ECs [121], which in turn leads to activation of NOX2.

\section{The Role of p66Shc in Crosstalk between NOX and Mitochondria Promoting Angiogenesis}

The mechanism by which Nox4/Nox2-derived ROS stimulate mitoROS production remains unclear. In addition to ETC, one of key regulators of mitoROS is an adaptor protein, p66Shc. Once p66shc is phosphorylated at the Serine (Ser) 36 residue in the cytosol, it translocates to mitochondria where it oxidizes cytochrome $\mathrm{c}$ to generate $\mathrm{H}_{2} \mathrm{O}_{2}$ (Figure 5) [122,123].

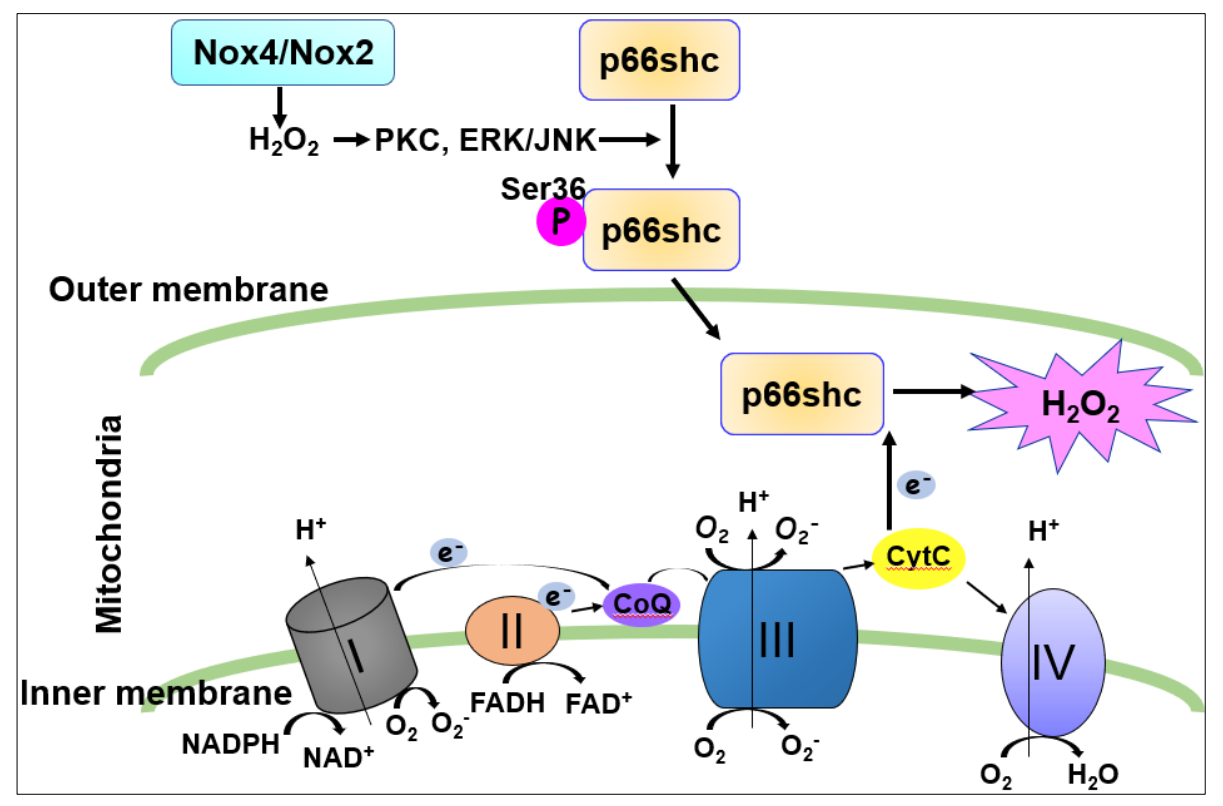

Figure 5. Mitochondrial $\mathrm{H}_{2} \mathrm{O}_{2}$ production via the Nox4/Nox2/p-p66Shc axis.

We reported that VEGF induces rapid Rac1 activation by interaction with the non-phosphorylated form of p66shc, leading to Nox2-dependent ROS production, which contributes to VEGFR2 phosphorylation at caveolae/lipid rafts and subsequent angiogenic responses in ECs [124]. It is also shown that p66shc regulates cytosolic Nox organizer p47phox expression, which in turn regulates ROS generation [22,125]. We also reported that VEGF increases phosphorylation of p66Shc at Ser36 [124] by protein kinase $\mathrm{C}(\mathrm{PKC})$ and extracellular signal regulated kinase (ERK)/Jun $N$-terminal kinase (JNK), which are activated by Nox-derived $\mathrm{H}_{2} \mathrm{O}$. This in turn increases mitoROS production that promotes sustained ROS-dependent VEGFR2 signaling and angiogenic responses [13]. This may represent a novel feed-forward mechanism of ROS-induced ROS release mediated through NOX-mitochondria cross-talk orchestrated by p-p66shc, which drives sustained growth-related angiogenic signaling programs in ECs $[13,113]$ (Figure 6).

Furthermore, using binary (Tet-ON/OFF) conditional EC-specific Nox2 transgenic mice, Shafique et al. reported that the duration of the increase in NOX2-derived ROS determines the level of mitoROS and their paradoxical effects (beneficial vs. harmful) on the coronary endothelium [126]. They showed that short-term (eight weeks) increases in NOX2-ROS induce the AMP-activated protein kinase (AMPK)-eNOS-NO axis with low mitoROS, thereby promoting angiogenesis. However, long-term (20 weeks) increases in cytosolic NOX2-ROS result in nitro-Tyrosine-mediated inactivation of MnSOD, leading to a sustained mitoROS increase that induces the loss of mitochondrial membrane potential, which in turn inhibits angiogenesis. These results suggest that the Nox2-derived ROS duration can regulate mitoROS levels and their fate in ECs. However, it remains unknown whether short-term and long-term increased NOX2-ROS mice models may reflect endogenous physiological 
and pathological (i.e., diabetes or aging) conditions, respectively, or levels of p-p66Shc at different extents or durations.

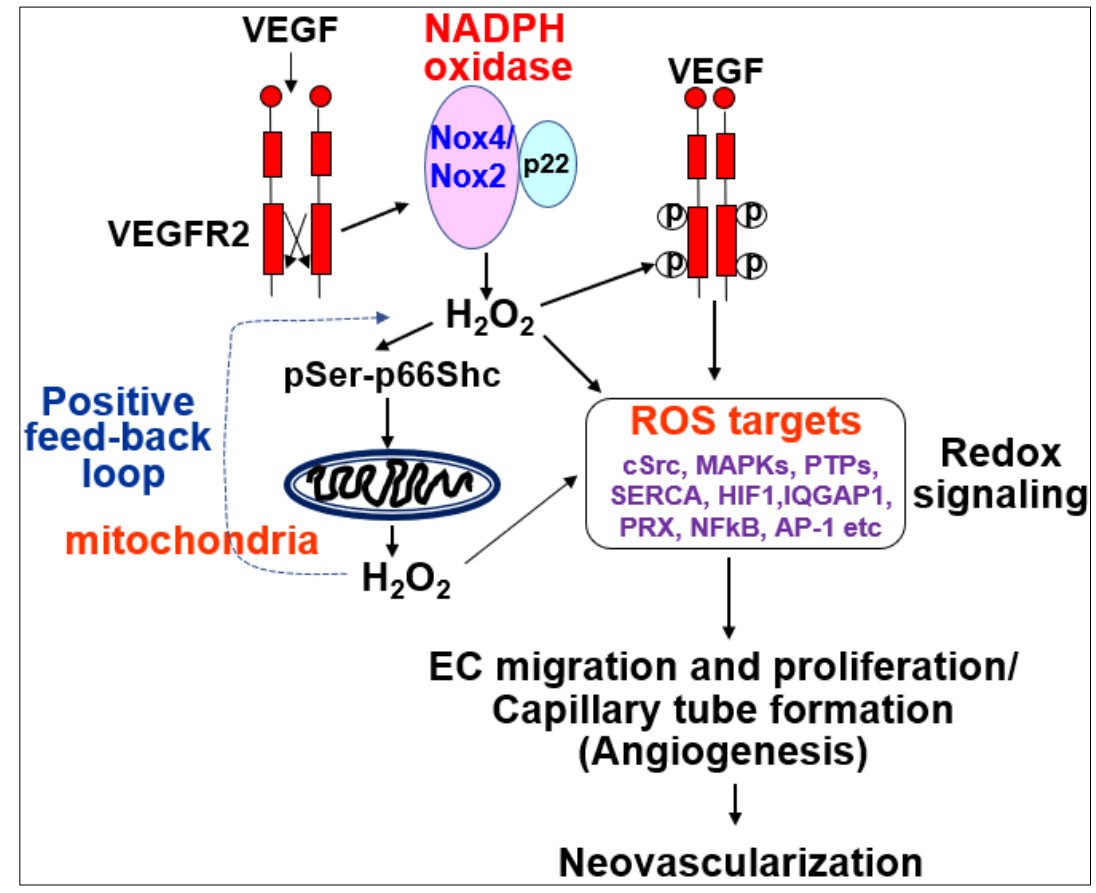

Figure 6. NOX-mitochondria cross-talk in VGEF signaling and angiogenesis.

\section{Summary and Future Perspectives}

From this review, it is clear that ROS-induced ROS release by the cross-talk between NOX-and mitochondria-derived ROS is essential for sustained angiogenic signaling, reparative angiogenesis and homeostatic maintenance of healthy vasculature. On the other hand, it can be toxic by amplifying ROS in excess, which will ultimately contribute to pathological angiogenesis and tissue damages in CAD, diabetes and aging. Multifaced ROS targets such as sulfenylated proteins or S-glutathionylated proteins or other cysteine-oxidized proteins in ROS-induced physiological or pathological angiogenesis are still poorly understood. Therefore, the systemic approach and measurement of ROS using compartment-specific redox-sensitive fluorescence biosensors in real time may need to understand the temporal and spatial modulation of ROS production and signaling involved in angiogenesis and vascular repair. In addition, using ROS or ROS-generating/blocking agents for therapy does not work always efficiently due to the lack of technology or information for their delivery to the distinct subcellular compartments. Thus, developing a new therapeutic strategy which specifically targets the ROS-induced ROS release mechanisms using specific inhibitors of NOX or mitochondria is important for treatment of various angiogenesis-dependent diseases such as ischemic heart and limb diseases, diabetic retinopathy and cancer.

Funding: This work was supported by National Institute of Health grants: R01HL135584 (to M.U.-F.), R01HL147550 (to M.U.-F., T.F.), R01HL133613 (to T.F., M.U.-F.), R01HL116976 (to T.F., M.U.-F.), R01HL070187 (to T.F.), Veterans Administration Merit Review Award 2I01BX001232 (to T.F.).

Conflicts of Interest: The authors declare that they have no competing interests.

\section{References}

1. Carmeliet, P.; Jain, R.K. Molecular mechanisms and clinical applications of angiogenesis. Nature 2011, 473, 298-307. [CrossRef] [PubMed]

2. Simons, M.; Gordon, E.; Claesson-Welsh, L. Mechanisms and regulation of endothelial VEGF receptor signalling. Nat. Rev. Mol. Cell Biol. 2016, 17, 611-625. [CrossRef] [PubMed] 
3. Simons, M. An inside view: VEGF receptor trafficking and signaling. Physiology (Bethesda) 2012, 27, $213-222$. [CrossRef] [PubMed]

4. Griendling, K.K.; Sorescu, D.; Ushio-Fukai, M. NAD(P)H oxidase: Role in cardiovascular biology and disease. Circ. Res. 2000, 86, 494-501. [CrossRef]

5. Finkel, T. Signal transduction by reactive oxygen species. J. Cell Biol. 2011, 194, 7-15. [CrossRef]

6. Ushio-Fukai, M. Localizing NADPH oxidase-derived ROS. Science STIKE 2006, 349, re8. [CrossRef]

7. Terada, L.S. Specificity in reactive oxidant signaling: Think globally, act locally. J. Cell Biol. 2006, 174, 615-623. [CrossRef]

8. Ushio-Fukai, M. Compartmentalization of redox signaling through NADPH oxidase-derived ROS. Antioxid. Redox Signal. 2009, 11, 1289-1299. [CrossRef]

9. Chen, K.; Craige, S.E.; Keaney, J.F., Jr. Downstream targets and intracellular compartmentalization in Nox signaling. Antioxid. Redox Signa.l 2009, 11, 2467-2480. [CrossRef]

10. Zhang, D.X.; Gutterman, D.D. Mitochondrial reactive oxygen species-mediated signaling in endothelial cells. Am. J. Physiol. Heart Circ. Physiol. 2007, 292, H2023-H2031. [CrossRef]

11. Finkel, T. Signal transduction by mitochondrial oxidants. J. Biol. Chem. 2012, 287, 4434-4440. [CrossRef] [PubMed]

12. Chandel, N.S. Evolution of Mitochondria as Signaling Organelles. Cell Metab. 2015, 22, 204-206. [CrossRef] [PubMed]

13. Kim, Y.M.; Kim, S.J.; Tatsunami, R.; Yamamura, H.; Fukai, T.; Ushio-Fukai, M. ROS-induced ROS release orchestrated by Nox4, Nox2, and mitochondria in VEGF signaling and angiogenesis. Am. J. Physiol. Cell Physiol. 2017, 312, C749-C764. [CrossRef] [PubMed]

14. Zorov, D.B.; Filburn, C.R.; Klotz, L.O.; Zweier, J.L.; Sollott, S.J. Reactive oxygen species (ROS)-induced ROS release: A new phenomenon accompanying induction of the mitochondrial permeability transition in cardiac myocytes. J. Exp. Med. 2000, 192, 1001-1014. [CrossRef] [PubMed]

15. Zinkevich, N.S.; Gutterman, D.D. ROS-induced ROS release in vascular biology: Redox-redox signaling. Am. J. Physiol. Heart Circ. Physiol. 2011, 301, H647-H653. [CrossRef]

16. Li, W.G.; Miller, F.J., Jr.; Zhang, H.J.; Spitz, D.R.; Oberley, L.W.; Weintraub, N.L. H(2)O(2)-induced O(2) production by a non-phagocytic NAD(P)H oxidase causes oxidant injury. J. Biol. Chem. 2001, 276, 29251-29256. [CrossRef]

17. Kuzkaya, N.; Weissmann, N.; Harrison, D.G.; Dikalov, S. Interactions of peroxynitrite, tetrahydrobiopterin, ascorbic acid, and thiols: Implications for uncoupling endothelial nitric-oxide synthase. J. Biol. Chem. 2003, 278, 22546-22554. [CrossRef]

18. Radi, R.; Cassina, A.; Hodara, R.; Quijano, C.; Castro, L. Peroxynitrite reactions and formation in mitochondria. Free Radic. Biol. Med. 2002, 33, 1451-1464. [CrossRef]

19. Dikalov, S. Cross talk between mitochondria and NADPH oxidases. Free Radic. Biol. Med. 2011, 51, $1289-1301$. [CrossRef]

20. Daiber, A. Redox signaling (cross-talk) from and to mitochondria involves mitochondrial pores and reactive oxygen species. Biochim. Biophys. Acta 2010, 1797, 897-906. [CrossRef]

21. Kim, Y.W.; Byzova, T.V. Oxidative stress in angiogenesis and vascular disease. Blood 2014, 123, 625-631. [CrossRef] [PubMed]

22. Aldosari, S.; Awad, M.; Harrington, E.O.; Sellke, F.W.; Abid, M.R. Subcellular Reactive Oxygen Species (ROS) in Cardiovascular Pathophysiology. Antioxidants (Basel) 2018, 7, 14. [CrossRef]

23. Zinkevich, N.S.; Fancher, I.S.; Gutterman, D.D.; Phillips, S.A. Roles of NADPH oxidase and mitochondria in flow-induced vasodilation of human adipose arterioles: ROS-induced ROS release in coronary artery disease. Microcirculation 2017, 24, e12380. [CrossRef] [PubMed]

24. Ushio-Fukai, M.; Alexander, R.W. Reactive oxygen species as mediators of angiogenesis signaling: Role of NAD(P)H oxidase. Mol. Cell Biochem. 2004, 264, 85-97. [CrossRef] [PubMed]

25. Bochkov, V.N.; Philippova, M.; Oskolkova, O.; Kadl, A.; Furnkranz, A.; Karabeg, E.; Afonyushkin, T.; Gruber, F.; Breuss, J.; Minchenko, A.; et al. Oxidized phospholipids stimulate angiogenesis via autocrine mechanisms, implicating a novel role for lipid oxidation in the evolution of atherosclerotic lesions. Circ. Res. 2006, 99, 900-908. [CrossRef] [PubMed]

26. Podrez, E.A.; Poliakov, E.; Shen, Z.; Zhang, R.; Deng, Y.; Sun, M.; Finton, P.J.; Shan, L.; Febbraio, M.; Hajjar, D.P.; et al. A novel family of atherogenic oxidized phospholipids promotes macrophage foam cell formation via the scavenger receptor CD36 and is enriched in atherosclerotic lesions. J. Biol. Chem. 2002, 277, 38517-38523. [CrossRef] 
27. Ushio-Fukai, M. Redox signaling in angiogenesis: Role of NADPH oxidase. Cardiovasc. Res. 2006, 71, 226-235. [CrossRef]

28. Ushio-Fukai, M. VEGF signaling through NADPH oxidase-derived ROS. Antioxid. Redox Signal. 2007, 9, 731-739. [CrossRef]

29. Ushio-Fukai, M.; Urao, N. Novel role of NADPH oxidase in angiogenesis and stem/progenitor cell function. Antioxid. Redox Signal. 2009, 11, 2517-2533. [CrossRef]

30. Gonzalez-Pacheco, F.R.; Deudero, J.J.; Castellanos, M.C.; Castilla, M.A.; Alvarez-Arroyo, M.V.; Yague, S.; Caramelo, C. Mechanisms of endothelial response to oxidative aggression: Protective role of autologous VEGF and induction of VEGFR2 by H2O2. Am. J. Physiol. Heart Circ. Physiol. 2006, 291, H1395-H1401. [CrossRef]

31. Chua, C.C.; Hamdy, R.C.; Chua, B.H. Upregulation of vascular endothelial growth factor by $\mathrm{H} 2 \mathrm{O} 2$ in rat heart endothelial cells. Free Radic. Biol. Med. 1998, 25, 891-897. [CrossRef]

32. Yasuda, M.; Shimizu, S.; Tokuyama, S.; Watanabe, T.; Kiuchi, Y.; Yamamoto, T. A novel effect of polymorphonuclear leukocytes in the facilitation of angiogenesis. Life Sci. 2000, 66, 2113-2121. [CrossRef]

33. Schreml, S.; Szeimies, R.M.; Prantl, L.; Karrer, S.; Landthaler, M.; Babilas, P. Oxygen in acute and chronic wound healing. Br. J. Derm. 2010, 163, 257-268. [CrossRef] [PubMed]

34. Knighton, D.R.; Hunt, T.K.; Scheuenstuhl, H.; Halliday, B.J.; Werb, Z.; Banda, M.J. Oxygen tension regulates the expression of angiogenesis factor by macrophages. Science 1983, 221, 1283-1285. [CrossRef]

35. Urao, N.; Sudhahar, V.; Kim, S.J.; Chen, G.F.; McKinney, R.D.; Kojda, G.; Fukai, T.; Ushio-Fukai, M. Critical role of endothelial hydrogen peroxide in post-ischemic neovascularization. PLoS ONE 2013, 8, e57618. [CrossRef]

36. Ikeda, S.; Ushio-Fukai, M.; Zuo, L.; Tojo, T.; Dikalov, S.; Patrushev, N.A.; Alexander, R.W. Novel role of ARF6 in vascular endothelial growth factor-induced signaling and angiogenesis. Circ. Res. 2005, 96, 467-475. [CrossRef]

37. Burgoyne, J.R.; Rudyk, O.; Cho, H.J.; Prysyazhna, O.; Hathaway, N.; Weeks, A.; Evans, R.; Ng, T.; Schroder, K.; Brandes, R.P.; et al. Deficient angiogenesis in redox-dead Cys17Ser PKARIalpha knock-in mice. Nat. Commun. 2015, 6, 7920. [CrossRef]

38. Kang, D.H.; Lee, D.J.; Lee, K.W.; Park, Y.S.; Lee, J.Y.; Lee, S.H.; Koh, Y.J.; Koh, G.Y.; Choi, C.; Yu, D.Y.; et al. Peroxiredoxin II is an essential antioxidant enzyme that prevents the oxidative inactivation of VEGF receptor-2 in vascular endothelial cells. Mol. Cell 2011, 44, 545-558. [CrossRef]

39. Kim, Y.M.; Youn, S.W.; Sudhahar, V.; Das, A.; Chandhri, R.; Cuervo Grajal, H.; Kweon, J.; Leanhart, S.; He, L.; Toth, P.T.; et al. Redox Regulation of Mitochondrial Fission Protein Drp1 by Protein Disulfide Isomerase Limits Endothelial Senescence. Cell Rep. 2018, 23, 3565-3578. [CrossRef]

40. Brandes, R.P.; Schroder, K. Composition and functions of vascular nicotinamide adenine dinucleotide phosphate oxidases. Trends Cardiovasc. Med. 2008, 18, 15-19. [CrossRef]

41. Brandes, R.P.; Weissmann, N.; Schroder, K. Nox family NADPH oxidases: Molecular mechanisms of activation. Free Radic. Biol. Med. 2014, 76, 208-226. [CrossRef] [PubMed]

42. Buvelot, H.; Jaquet, V.; Krause, K.H. Mammalian NADPH Oxidases. Methods Mol. Biol. 2019, 1982, 17-36. [CrossRef] [PubMed]

43. Grasberger, H.; Refetoff, S. Identification of the maturation factor for dual oxidase. Evolution of an eukaryotic operon equivalent. J. Biol. Chem. 2006, 281, 18269-18272. [CrossRef] [PubMed]

44. Lassegue, B.; Griendling, K.K. NADPH oxidases: Functions and pathologies in the vasculature. Arter. Thromb. Vasc. Biol. 2010, 30, 653-661. [CrossRef] [PubMed]

45. Drummond, G.R.; Sobey, C.G. Endothelial NADPH oxidases: Which NOX to target in vascular disease? Trends Endocrinol. Metab. 2014, 25, 452-463. [CrossRef] [PubMed]

46. Nisimoto, Y.; Diebold, B.A.; Cosentino-Gomes, D.; Lambeth, J.D. Nox4: A hydrogen peroxide-generating oxygen sensor. Biochemistry 2014, 53, 5111-5120. [CrossRef]

47. Takac, I.; Schroder, K.; Zhang, L.; Lardy, B.; Anilkumar, N.; Lambeth, J.D.; Shah, A.M.; Morel, F.; Brandes, R.P. The E-loop is involved in hydrogen peroxide formation by the NADPH oxidase Nox4. J. Biol. Chem. 2011, 286, 13304-13313. [CrossRef]

48. Pandey, D.; Gratton, J.P.; Rafikov, R.; Black, S.M.; Fulton, D.J. Calcium/calmodulin-dependent kinase II mediates the phosphorylation and activation of NADPH oxidase 5. Mol. Pharm. 2011, 80, 407-415. [CrossRef] 
49. Overmyer, K.; Brosche, M.; Kangasjarvi, J. Reactive oxygen species and hormonal control of cell death. Trends Plant Sci. 2003, 8, 335-342. [CrossRef]

50. Bayraktutan, U.; Blayney, L.; Shah, A.M. Molecular characterization and localization of the NAD(P)H oxidase components gp91-phox and p22-phox in endothelial cells. Arter. Thromb. Vasc. Biol. 2000, 20, 1903-1911. [CrossRef]

51. Lyle, A.N.; Deshpande, N.N.; Taniyama, Y.; Seidel-Rogol, B.; Pounkova, L.; Du, P.; Papaharalambus, C.; Lassegue, B.; Griendling, K.K. Poldip2, a novel regulator of Nox4 and cytoskeletal integrity in vascular smooth muscle cells. Circ. Res. 2009, 105, 249-259. [CrossRef] [PubMed]

52. Paredes, F.; Sheldon, K.; Lassegue, B.; Williams, H.C.; Faidley, E.A.; Benavides, G.A.; Torres, G.; Sanhueza-Olivares, F.; Yeligar, S.M.; Griendling, K.K.; et al. Poldip2 is an oxygen-sensitive protein that controls $\mathrm{PDH}$ and alphaKGDH lipoylation and activation to support metabolic adaptation in hypoxia and cancer. Proc Natl. Acad. Sci. USA 2018, 115, 1789-1794. [CrossRef] [PubMed]

53. Paredes, F.; Williams, H.C.; Quintana, R.A.; San Martin, A. Mitochondrial Protein Poldip2 (Polymerase Delta Interacting Protein 2) Controls Vascular Smooth Muscle Differentiated Phenotype by O-Linked GlcNAc (N-Acetylglucosamine) Transferase-Dependent Inhibition of a Ubiquitin Proteasome System. Circ. Res. 2020, 126, 41-56. [CrossRef] [PubMed]

54. Amanso, A.M.; Lassegue, B.; Joseph, G.; Landazuri, N.; Long, J.S.; Weiss, D.; Taylor, W.R.; Griendling, K.K. Polymerase delta-interacting protein 2 promotes postischemic neovascularization of the mouse hindlimb. Arter. Thromb. Vasc. Biol. 2014, 34, 1548-1555. [CrossRef]

55. Prior, K.K.; Wittig, I.; Leisegang, M.S.; Groenendyk, J.; Weissmann, N.; Michalak, M.; Jansen-Durr, P.; Shah, A.M.; Brandes, R.P. The Endoplasmic Reticulum Chaperone Calnexin Is a NADPH Oxidase NOX4 Interacting Protein. J. Biol. Chem. 2016, 291, 7045-7059. [CrossRef]

56. Wang, H.; Hartnett, M.E. Roles of Nicotinamide Adenine Dinucleotide Phosphate (NADPH) Oxidase in Angiogenesis: Isoform-Specific Effects. Antioxidantds (Basel) 2017, 6, 40. [CrossRef]

57. Petry, A.; Djordjevic, T.; Weitnauer, M.; Kietzmann, T.; Hess, J.; Gorlach, A. NOX2 and NOX4 mediate proliferative response in endothelial cells. Antioxid. Redox Signal. 2006, 8, 1473-1484. [CrossRef]

58. Pendyala, S.; Gorshkova, I.A.; Usatyuk, P.V.; He, D.; Pennathur, A.; Lambeth, J.D.; Thannickal, V.J.; Natarajan, V. Role of Nox4 and Nox2 in hyperoxia-induced reactive oxygen species generation and migration of human lung endothelial cells. Antioxid. Redox Signal. 2009, 11, 747-764. [CrossRef]

59. Chen, L.; Xiao, J.; Kuroda, J.; Ago, T.; Sadoshima, J.; Cohen, R.A.; Tong, X. Both hydrogen peroxide and transforming growth factor beta 1 contribute to endothelial Nox4 mediated angiogenesis in endothelial Nox4 transgenic mouse lines. Biochim. Biophys. Acta 2014, 1842, 2489-2499. [CrossRef]

60. Peshavariya, H.M.; Chan, E.C.; Liu, G.S.; Jiang, F.; Dusting, G.J. Transforming growth factor-beta1 requires NADPH oxidase 4 for angiogenesis in vitro and in vivo. J. Cell Mol. Med. 2014, 18, 1172-1183. [CrossRef]

61. Zhuang, J.; Jiang, T.; Lu, D.; Luo, Y.; Zheng, C.; Feng, J.; Yang, D.; Chen, C.; Yan, X. NADPH oxidase 4 mediates reactive oxygen species induction of CD146 dimerization in VEGF signal transduction. Free Radic. Biol. Med. 2010, 49, 227-236. [CrossRef] [PubMed]

62. Wang, H.; Yang, Z.; Jiang, Y.; Hartnett, M.E. Endothelial NADPH oxidase 4 mediates vascular endothelial growth factor receptor 2-induced intravitreal neovascularization in a rat model of retinopathy of prematurity. Mol. Vis. 2014, 20, 231-241. [PubMed]

63. Wang, J.; Hong, Z.; Zeng, C.; Yu, Q.; Wang, H. NADPH oxidase 4 promotes cardiac microvascular angiogenesis after hypoxia/reoxygenation in vitro. Free Radic. Biol. Med. 2014, 69, 278-288. [CrossRef] [PubMed]

64. Craige, S.M.; Kant, S.; Keaney, J.F., Jr. Reactive oxygen species in endothelial function - from disease to adaptation. Circ. J. 2015, 79, 1145-1155. [CrossRef] [PubMed]

65. Evangelista, A.M.; Thompson, M.D.; Bolotina, V.M.; Tong, X.; Cohen, R.A. Nox4- and Nox2-dependent oxidant production is required for VEGF-induced SERCA cysteine-674 S-glutathiolation and endothelial cell migration. Free Radic. Biol. Med. 2012, 53, 2327-2334. [CrossRef]

66. Yamaoka-Tojo, M.; Ushio-Fukai, M.; Hilenski, L.; Dikalov, S.I.; Chen, Y.E.; Tojo, T.; Fukai, T.; Fujimoto, M.; Patrushev, N.A.; Wang, N.; et al. IQGAP1, a novel vascular endothelial growth factor receptor binding protein, is involved in reactive oxygen species-dependent endothelial migration and proliferation. Circ. Res. 2004, 95, 276-283. [CrossRef]

67. Abid, M.R.; Spokes, K.C.; Shih, S.C.; Aird, W.C. NADPH oxidase activity selectively modulates vascular endothelial growth factor signaling pathways. J. Biol. Chem. 2007, 282, 35373-35385. [CrossRef] 
68. Urao, N.; Inomata, H.; Razvi, M.; Kim, H.W.; Wary, K.; McKinney, R.; Fukai, T.; Ushio-Fukai, M. Role of nox2-based NADPH oxidase in bone marrow and progenitor cell function involved in neovascularization induced by hindlimb ischemia. Circ. Res. 2008, 103, 212-220. [CrossRef]

69. Craige, S.M.; Chen, K.; Pei, Y.; Li, C.; Huang, X.; Chen, C.; Shibata, R.; Sato, K.; Walsh, K.; Keaney, J.F., Jr. NADPH oxidase 4 promotes endothelial angiogenesis through endothelial nitric oxide synthase activation. Circulation 2011, 124, 731-740. [CrossRef]

70. Sirker, A.; Zhang, M.; Shah, A.M. NADPH oxidases in cardiovascular disease: Insights from in vivo models and clinical studies. Basic Res. Cardiol. 2011, 106, 735-747. [CrossRef]

71. Schroder, K.; Zhang, M.; Benkhoff, S.; Mieth, A.; Pliquett, R.; Kosowski, J.; Kruse, C.; Luedike, P.; Michaelis, U.R.; Weissmann, N.; et al. Nox4 is a protective reactive oxygen species generating vascular NADPH oxidase. Circ. Res. 2012, 110, 1217-1225. [CrossRef] [PubMed]

72. Chan, E.C.; van Wijngaarden, P.; Liu, G.S.; Jiang, F.; Peshavariya, H.; Dusting, G.J. Involvement of Nox2 NADPH oxidase in retinal neovascularization. Investig. Ophthalmol. Vis. Sci. 2013, 54, 7061-7067. [CrossRef] [PubMed]

73. Chen, G.F.; Sudhahar, V.; Youn, S.W.; Das, A.; Cho, J.; Kamiya, T.; Urao, N.; McKinney, R.D.; Surenkhuu, B.; Hamakubo, T.; et al. Copper Transport Protein Antioxidant-1 Promotes Inflammatory Neovascularization via Chaperone and Transcription Factor Function. Sci. Rep. 2015, 5, 14780. [CrossRef] [PubMed]

74. Vogel, J.; Kruse, C.; Zhang, M.; Schroder, K. Nox4 supports proper capillary growth in exercise and retina neo-vascularization. J. Physiol. 2015, 593, 2145-2154. [CrossRef] [PubMed]

75. Helfinger, V.; Henke, N.; Harenkamp, S.; Walter, M.; Epah, J.; Penski, C.; Mittelbronn, M.; Schroder, K. The NADPH Oxidase Nox4 mediates tumour angiogenesis. Acta Physiol. (Oxford) 2016, 216, 435-446. [CrossRef] [PubMed]

76. Rivera, J.; Sobey, C.G.; Walduck, A.K.; Drummond, G.R. Nox isoforms in vascular pathophysiology: Insights from transgenic and knockout mouse models. Redox Rep. 2010, 15, 50-63. [CrossRef] [PubMed]

77. Ebrahimian, T.G.; Heymes, C.; You, D.; Blanc-Brude, O.; Mees, B.; Waeckel, L.; Duriez, M.; Vilar, J.; Brandes, R.P.; Levy, B.I.; et al. NADPH oxidase-derived overproduction of reactive oxygen species impairs postischemic neovascularization in mice with type 1 diabetes. Am. J. Pathol. 2006, 169, 719-728. [CrossRef]

78. Sedeek, M.; Montezano, A.C.; Hebert, R.L.; Gray, S.P.; Di Marco, E.; Jha, J.C.; Cooper, M.E.; Jandeleit-Dahm, K.; Schiffrin, E.L.; Wilkinson-Berka, J.L.; et al. Oxidative stress, Nox isoforms and complications of diabetes-potential targets for novel therapies. J. Cardiovasc. Transl. Res. 2012, 5, 509-518. [CrossRef]

79. Kahles, T.; Luedike, P.; Endres, M.; Galla, H.J.; Steinmetz, H.; Busse, R.; Neumann-Haefelin, T.; Brandes, R.P. NADPH oxidase plays a central role in blood-brain barrier damage in experimental stroke. Stroke 2007, 38, 3000-3006. [CrossRef]

80. Bendall, J.K.; Rinze, R.; Adlam, D.; Tatham, A.L.; de Bono, J.; Wilson, N.; Volpi, E.; Channon, K.M. Endothelial Nox2 overexpression potentiates vascular oxidative stress and hemodynamic response to angiotensin II: Studies in endothelial-targeted Nox2 transgenic mice. Circ. Res. 2007, 100, 1016-1025. [CrossRef]

81. Murdoch, C.E.; Alom-Ruiz, S.P.; Wang, M.; Zhang, M.; Walker, S.; Yu, B.; Brewer, A.; Shah, A.M. Role of endothelial Nox2 NADPH oxidase in angiotensin II-induced hypertension and vasomotor dysfunction. Basic. Res. Cardiol. 2011, 106, 527-538. [CrossRef] [PubMed]

82. Sag, C.M.; Schnelle, M.; Zhang, J.; Murdoch, C.E.; Kossmann, S.; Protti, A.; Santos, C.X.C.; Sawyer, G.; Zhang, X.; Mongue-Din, H.; et al. Distinct Regulatory Effects of Myeloid Cell and Endothelial Cell NAPDH Oxidase 2 on Blood Pressure. Circulation 2017, 135, 2163-2177. [CrossRef] [PubMed]

83. Chen, K.; Kirber, M.T.; Xiao, H.; Yang, Y.; Keaney, J.F., Jr. Regulation of ROS signal transduction by NADPH oxidase 4 localization. J. Cell Biol. 2008, 181, 1129-1139. [CrossRef] [PubMed]

84. Chen, F.; Haigh, S.; Barman, S.; Fulton, D.J. From form to function: The role of Nox4 in the cardiovascular system. Front. Physiol. 2012, 3, 412. [CrossRef]

85. Poole, L.B.; Karplus, P.A.; Claiborne, A. Protein sulfenic acids in redox signaling. Annu. Rev Pharm. Toxicol. 2004, 44, 325-347. [CrossRef]

86. Ikeda, S.; Yamaoka-Tojo, M.; Hilenski, L.; Patrushev, N.A.; Anwar, G.M.; Quinn, M.T.; Ushio-Fukai, M. IQGAP1 regulates reactive oxygen species-dependent endothelial cell migration through interacting with Nox2. Arter. Thromb. Vasc. Biol. 2005, 25, 2295-2300. [CrossRef] 
87. Kaplan, N.; Urao, N.; Furuta, E.; Kim, S.J.; Razvi, M.; Nakamura, Y.; McKinney, R.D.; Poole, L.B.; Fukai, T.; Ushio-Fukai, M. Localized cysteine sulfenic acid formation by vascular endothelial growth factor: Role in endothelial cell migration and angiogenesis. Free Radic. Res. 2011, 45, 1124-1135. [CrossRef]

88. Urao, N.; Razvi, M.; Oshikawa, J.; McKinney, R.D.; Chavda, R.; Bahou, W.F.; Fukai, T.; Ushio-Fukai, M. IQGAP1 is involved in post-ischemic neovascularization by regulating angiogenesis and macrophage infiltration. PLoS ONE 2010, 5, e13440. [CrossRef]

89. Oshikawa, J.; Urao, N.; Kim, H.W.; Kaplan, N.; Razvi, M.; McKinney, R.; Poole, L.B.; Fukai, T.; Ushio-Fukai, M. Extracellular SOD-derived $\mathrm{H} 2 \mathrm{O} 2$ promotes VEGF signaling in caveolae/lipid rafts and post-ischemic angiogenesis in mice. PLoS ONE 2010, 5, e10189. [CrossRef]

90. Go, Y.M.; Jones, D.P. Redox compartmentalization in eukaryotic cells. Biochim. Biophys. Acta 2008, 1780, 1273-1290. [CrossRef]

91. Kumari, S.; Badana, A.K.; G, M.M.; G, S.; Malla, R. Reactive Oxygen Species: A Key Constituent in Cancer Survival. Biomark. Insights 2018, 13, 1177271918755391. [CrossRef] [PubMed]

92. St-Pierre, J.; Buckingham, J.A.; Roebuck, S.J.; Brand, M.D. Topology of superoxide production from different sites in the mitochondrial electron transport chain. J. Biol. Chem. 2002, 277, 44784-44790. [CrossRef] [PubMed]

93. Han, D.; Antunes, F.; Canali, R.; Rettori, D.; Cadenas, E. Voltage-dependent anion channels control the release of the superoxide anion from mitochondria to cytosol. J. Biol. Chem. 2003, 278, 5557-5563. [CrossRef] [PubMed]

94. Chandel, N.S.; McClintock, D.S.; Feliciano, C.E.; Wood, T.M.; Melendez, J.A.; Rodriguez, A.M.; Schumacker, P.T. Reactive oxygen species generated at mitochondrial complex III stabilize hypoxia-inducible factor-1alpha during hypoxia: A mechanism of $\mathrm{O} 2$ sensing. J. Biol. Chem. 2000, 275, 25130-25138. [CrossRef] [PubMed]

95. Klimova, T.; Chandel, N.S. Mitochondrial complex III regulates hypoxic activation of HIF. Cell Death Differ. 2008, 15, 660-666. [CrossRef] [PubMed]

96. Guzy, R.D.; Hoyos, B.; Robin, E.; Chen, H.; Liu, L.; Mansfield, K.D.; Simon, M.C.; Hammerling, U.; Schumacker, P.T. Mitochondrial complex III is required for hypoxia-induced ROS production and cellular oxygen sensing. Cell Metab. 2005, 1, 401-408. [CrossRef]

97. Reichard, A.; Asosingh, K. The role of mitochondria in angiogenesis. Mol. Biol. Rep. 2019, 46, $1393-1400$. [CrossRef]

98. Wang, Y.; Zang, Q.S.; Liu, Z.; Wu, Q.; Maass, D.; Dulan, G.; Shaul, P.W.; Melito, L.; Frantz, D.E.; Kilgore, J.A.; et al. Regulation of VEGF-induced endothelial cell migration by mitochondrial reactive oxygen species. Am. J. Physiol. Cell Physiol. 2011, 301, C695-C704. [CrossRef]

99. Harel, S.; Mayaki, D.; Sanchez, V.; Hussain, S.N.A. NOX2, NOX4, and mitochondrial-derived reactive oxygen species contribute to angiopoietin-1 signaling and angiogenic responses in endothelial cells. Vasc. Pharm. 2017, 92, 22-32. [CrossRef]

100. Diebold, L.P.; Gil, H.J.; Gao, P.; Martinez, C.A.; Weinberg, S.E.; Chandel, N.S. Mitochondrial complex III is necessary for endothelial cell proliferation during angiogenesis. Nat. Metab. 2019, 1, 158-171. [CrossRef]

101. Chen, K.; Thomas, S.R.; Albano, A.; Murphy, M.P.; Keaney, J.F., Jr. Mitochondrial function is required for hydrogen peroxide-induced growth factor receptor transactivation and downstream signaling. J. Biol. Chem. 2004, 279, 35079-35086. [CrossRef] [PubMed]

102. Warren, C.M.; Ziyad, S.; Briot, A.; Der, A.; Iruela-Arispe, M.L. A ligand-independent VEGFR2 signaling pathway limits angiogenic responses in diabetes. Sci. Signal. 2014, 7, ra1. [CrossRef] [PubMed]

103. Chung, Y.M.; Bae, Y.S.; Lee, S.Y. Molecular ordering of ROS production, mitochondrial changes, and caspase activation during sodium salicylate-induced apoptosis. Free Radic. Biol. Med. 2003, 34, 434-442. [CrossRef]

104. Zorov, D.B.; Juhaszova, M.; Sollott, S.J. Mitochondrial ROS-induced ROS release: An update and review. Biochim. Biophys. Acta 2006, 1757, 509-517. [CrossRef] [PubMed]

105. Aon, M.A.; Cortassa, S.; O'Rourke, B. The fundamental organization of cardiac mitochondria as a network of coupled oscillators. Biophys. J. 2006, 91, 4317-4327. [CrossRef] [PubMed]

106. Aon, M.A.; Cortassa, S.; O'Rourke, B. Mitochondrial oscillations in physiology and pathophysiology. Adv. Exp. Med. Biol. 2008, 641, 98-117. [CrossRef] [PubMed]

107. Bak, D.W.; Weerapana, E. Cysteine-mediated redox signalling in the mitochondria. Mol. Biosyst. 2015, 11, 678-697. [CrossRef] 
108. Tsai, I.C.; Pan, Z.C.; Cheng, H.P.; Liu, C.H.; Lin, B.T.; Jiang, M.J. Reactive oxygen species derived from NADPH oxidase 1 and mitochondria mediate angiotensin II-induced smooth muscle cell senescence. J. Mol. Cell. Cardiol. 2016, 98, 18-27. [CrossRef]

109. Salazar, G. NADPH Oxidases and Mitochondria in Vascular Senescence. Int. J. Mol. Sci. 2018, 19, 1327. [CrossRef]

110. Dikalov, S.I.; Nazarewicz, R.R.; Bikineyeva, A.; Hilenski, L.; Lassegue, B.; Griendling, K.K.; Harrison, D.G.; Dikalova, A.E. Nox2-induced production of mitochondrial superoxide in angiotensin II-mediated endothelial oxidative stress and hypertension. Antioxid. Redox Signal. 2014, 20, 281-294. [CrossRef]

111. Kroller-Schon, S.; Steven, S.; Kossmann, S.; Scholz, A.; Daub, S.; Oelze, M.; Xia, N.; Hausding, M.; Mikhed, Y.; Zinssius, E.; et al. Molecular mechanisms of the crosstalk between mitochondria and NADPH oxidase through reactive oxygen species-studies in white blood cells and in animal models. Antioxid. Redox Signal. 2014, 20, 247-266. [CrossRef] [PubMed]

112. Wosniak, J., Jr.; Santos, C.X.; Kowaltowski, A.J.; Laurindo, F.R. Cross-talk between mitochondria and NADPH oxidase: Effects of mild mitochondrial dysfunction on angiotensin II-mediated increase in Nox isoform expression and activity in vascular smooth muscle cells. Antioxid Redox Signal 2009, 11, 1265-1278. [CrossRef] [PubMed]

113. Waypa, G.B.; Marks, J.D.; Guzy, R.; Mungai, P.T.; Schriewer, J.; Dokic, D.; Schumacker, P.T. Hypoxia triggers subcellular compartmental redox signaling in vascular smooth muscle cells. Circ. Res. 2010, 106, 526-535. [CrossRef] [PubMed]

114. Bilan, D.S.; Pase, L.; Joosen, L.; Gorokhovatsky, A.Y.; Ermakova, Y.G.; Gadella, T.W.; Grabher, C.; Schultz, C.; Lukyanov, S.; Belousov, V.V. HyPer-3: A genetically encoded $\mathrm{H}(2) \mathrm{O}(2)$ probe with improved performance for ratiometric and fluorescence lifetime imaging. Acs. Chem. Biol. 2013, 8, 535-542. [CrossRef] [PubMed]

115. Griendling, K.K.; Touyz, R.M.; Zweier, J.L.; Dikalov, S.; Chilian, W.; Chen, Y.R.; Harrison, D.G.; Bhatnagar, A.; American Heart Association Council on Basic Cardiovascular Sciences. Measurement of Reactive Oxygen Species, Reactive Nitrogen Species, and Redox-Dependent Signaling in the Cardiovascular System: A Scientific Statement From the American Heart Association. Circ. Res. 2016, 119, 5. [CrossRef]

116. Rezende, F.; Brandes, R.P.; Schroder, K. Detection of Hydrogen Peroxide with Fluorescent Dyes. Antioxid. Redox Signal. 2018, 29, 585-602. [CrossRef]

117. Giorgi, C.; De Stefani, D.; Bononi, A.; Rizzuto, R.; Pinton, P. Structural and functional link between the mitochondrial network and the endoplasmic reticulum. Int. J. Biochem. Cell Biol. 2009, 41, 1817-1827. [CrossRef]

118. Marchi, S.; Patergnani, S.; Pinton, P. The endoplasmic reticulum-mitochondria connection: One touch, multiple functions. Biochim. Biophys. Acta 2014, 1837, 461-469. [CrossRef]

119. El-Benna, J.; Dang, P.M.; Gougerot-Pocidalo, M.A.; Marie, J.C.; Braut-Boucher, F. p47phox, the phagocyte NADPH oxidase/NOX2 organizer: Structure, phosphorylation and implication in diseases. Exp. Mol. Med. 2009, 41, 217-225. [CrossRef]

120. Servitja, J.M.; Marinissen, M.J.; Sodhi, A.; Bustelo, X.R.; Gutkind, J.S. Rac1 function is required for Src-induced transformation. Evidence of a role for Tiam1 and Vav2 in Rac activation by Src. J. Biol. Chem. 2003, 278, 34339-34346. [CrossRef]

121. Garrett, T.A.; Van Buul, J.D.; Burridge, K. VEGF-induced Rac1 activation in endothelial cells is regulated by the guanine nucleotide exchange factor Vav2. Exp. Cell Res. 2007, 313, 3285-3297. [CrossRef] [PubMed]

122. Giorgio, M.; Migliaccio, E.; Orsini, F.; Paolucci, D.; Moroni, M.; Contursi, C.; Pelliccia, G.; Luzi, L.; Minucci, S.; Marcaccio, M.; et al. Electron transfer between cytochrome $\mathrm{c}$ and p66Shc generates reactive oxygen species that trigger mitochondrial apoptosis. Cell 2005, 122, 221-233. [CrossRef] [PubMed]

123. Pinton, P.; Rimessi, A.; Marchi, S.; Orsini, F.; Migliaccio, E.; Giorgio, M.; Contursi, C.; Minucci, S.; Mantovani, F.; Wieckowski, M.R.; et al. Protein kinase $\mathrm{C}$ beta and prolyl isomerase 1 regulate mitochondrial effects of the life-span determinant p66Shc. Science 2007, 315, 659-663. [CrossRef] [PubMed]

124. Oshikawa, J.; Kim, S.J.; Furuta, E.; Caliceti, C.; Chen, G.F.; McKinney, R.D.; Kuhr, F.; Levitan, I.; Fukai, T.; Ushio-Fukai, M. Novel role of p66Shc in ROS-dependent VEGF signaling and angiogenesis in endothelial cells. Am. J. Physiol. Heart Circ. Physiol. 2012, 302, H724-H732. [CrossRef] [PubMed] 
125. Bosutti, A.; Grassi, G.; Zanetti, M.; Aleksova, A.; Zecchin, M.; Sinagra, G.; Biolo, G.; Guarnieri, G. Relation between the plasma levels of LDL-cholesterol and the expression of the early marker of inflammation long pentraxin PTX3 and the stress response gene p66ShcA in pacemaker-implanted patients. Clin. Exp. Med. 2007, 7, 16-23. [CrossRef]

126. Shafique, E.; Torina, A.; Reichert, K.; Colantuono, B.; Nur, N.; Zeeshan, K.; Ravichandran, V.; Liu, Y.; Feng, J.; Zeeshan, K.; et al. Mitochondrial redox plays a critical role in the paradoxical effects of NAPDH oxidase-derived ROS on coronary endothelium. Cardiovasc. Res. 2017, 113, 234-246. [CrossRef]

(C) 2020 by the authors. Licensee MDPI, Basel, Switzerland. This article is an open access article distributed under the terms and conditions of the Creative Commons Attribution (CC BY) license (http://creativecommons.org/licenses/by/4.0/). 